\title{
An Econometric Analysis of the Relationship between Changes in Government Bonds, Exchange Rate and Inflation Dynamics in South Africa
}

\author{
Sanusi, K. A., Meyer, D. F. \\ North-West University, South Africa \\ sanusikazeemabimbola@yahoo.com,daniel.meyer@nwu.ac.za
}

\begin{abstract}
The study examined the dynamic interaction between government bonds, exchange rate and inflation in South Africa. The study follows a quantitative research method, using monthly time series data from 2007 to 2017 within the framework of a Vector Autoregressive Analysis (VAR). Evidence from the empirical analysis shows that government bond accounts for significant variation in the exchange rate and inflation rate within the study period. The causality test also suggests the presence of uni-directional causal relationships from government bonds to exchange rate, and also to the inflation rate. The principal conclusion that emanates from the empirical analysis is that government bonds are an important policy instrument in the management of the exchange rate and the inflation rate in South Africa. The study recommends that the South African Reserve Bank is a coordinator of government bond and should carry out an in-depth analysis of the economic conditions before issuing the government bonds, taking into account its impeding effects on the exchange rate and inflation rate and many other macroeconomic variables.
\end{abstract}

Keywords: Exchange Rate; Government Bonds; Inflation; South Africa

\section{Introduction}

Due to increased government spending over the years, and with the inability of the revenue to match the upward trend in government spending, the government usually raises funds to finance the deficits through several means such as bond issuing, and seigniorage amongst others. However, financing government spending by means of seigniorage mostly has a deteriorating effect on the economy (Roubini \& Sala-i-Martin, 1995; Holman \& Neanidis, 2006). Seigniorage leads to increased money supply, which causes rising inflation (De Resende, 2007; Sanusi \& Akinlo, 2016). Rising inflation affects the total population but also the poor because they inexplicably are inclined to have cash rather than assets which are more negatively impacted by inflation (Gaffney, 2009). As a result, government bond becomes more appealing as an important debt security instrument issued by a government to finance government spending. In the case where government issues bonds to finance its deficit, it could result in stable and low inflation (Kalderen, 1997; Borensztein \& Mauro, 2004). Meanwhile, there exists a theoretical position in economic literature that increased government bonds imply an increase in demand for loanable funds which increase domestic interest rate (Gurley \& Shaw, 1995; Engen \& Hubbard, 2004; Lastrapes, 1998).

An increase in domestic interest rate may result to exchange rate appreciation if the interest rate rises above the world interest rate. This is due to the fact that if the interest rate rises above the world average interest rate, foreign investors would be motivated, thereby placing pressures on demand for domestic currency (Obstfeld \& Rogoff, 1995; Calvo \& Reinhart, 2002; Frankel, 2006; Gavin, 1989). On the other hand, an economy with large public debts perhaps by means of uncontrolled high government spending or leakages, is unattractive to foreign investors. This is because debt encourages high inflation which makes debt to be serviced and eventually paid off with cheaper real dollars in the future (Koller, Goedhart \& Wessels, 2010; Cavallo \& Fernández-Arias, 2013). Most of the existing available studies have largely examined the relationship between external debt and exchange rate (Neaime, 2009; Ezirim \& Muoghalu, 2006; Draz \& Ahmad, 2015). However, the majority of these empirical studies did not consider the roles of the internal debt in exchange rate behavior and the resultant effect on inflation was also not given much attention. This study considers the role of internal debt by making use of government bond which captures both internal and external indebtedness of government. The study also differs from existing studies by looking at the relationship between government bonds, exchange rate and inflation, and the possibility of feedbacks amongst the variables. The rest of the study is structured as follows: section two synthesizes the existing literature. Section three introduces the empirical approach while section four presents the results. The concluding remark is contained in section five. 


\section{Literature Review}

Neaime (2009) investigated the relationship between exchange rate behavior and external debt in five MENA countries (Jordon, Morocco, Egypt, Tunisia, and Turkey). Empirical findings suggest a positive relationship between external debt and exchange rate depreciation. Ajayi (1991) examined the relationship between the size of the external debt, world oil price and exchange rate. He employed a two-stage least squares simultaneous equation model, and empirical results showed that the size of the external debt had a negative, but the statistically insignificant impact on the external value of the Naira. This is consistent with the findings of Ezirim and Muoghalu (2006) who argued that the cost of external debt did put negative pressures on the exchange rate crisis instead of aggravating it. Similarly, Draz and Ahmad (2015) focused on the impact of external debt and world oil prices on the exchange rate. The results indicated that the exchange rate was significantly influenced by the external debt while no such evidence was found for the world oil prices. Also, Awan, Asghar and Rehman (2011) examined the impact of fiscal deficit, depreciation and unfavorable terms of trade on external debt. They argued that there is a significant long-run relationship between external debt and exchange rate.

Perri, Cavallo, Kisselev and Roubini (2004) worried why countries experiencing currency problem with high levels of foreign debt tended to experience large real exchange rate overshooting and consequently investigated the relationship among the variables. The evidence showed countries with severe foreign debt burden after currency crises experienced real exchange rate appreciation. In another dimension, Reza, Siregar and Pontines (2005) seek to investigate if the rapid accumulation of external debts is responsible for exchange rate problems of the four East Asian Currencies, the Indonesian Rupiah, Philippines Peso and Thai Baht and Korean Won. They conclude that external debts accumulation in the four economies were partly responsible for the increasing and worsening of exchange rate problems of the local currency. Sonoma (2013) explore the relationship between exchange rate depreciation and debts accumulation. The results show that in the pre-default periods, exchange rate depreciation triggers more debt accumulation and default. Whereas in the post-default periods, exchange rate experienced depreciation as a result of output costs of defaulting and loss of market access. Masuku (2001) probed the impacts of external debt on exchange rate fluctuations in Kenya. The study finds that that external debt had significant positive effects on the exchange rate. Conclusively, evidence from the literature shows that empirical studies aiming at the resultants effects of government bond and exchange rate nexus on inflation, and the possibility of feedbacks among the variables have not received adequate attention and consequently this study.

\section{Methodology}

The study follows a quantitative research method, using monthly time series data from 2007 to 2017 within the framework of a Vector Autoregressive Analysis (VAR). It is common in an empirical context to examine the dynamic relationship among macroeconomic variables using a VAR model. The model comprises of three variables which are government bonds (GB), exchange rate (ER) and inflation (INF). In terms of the model, $X_{t}$ denotes aseries of endogenously determined variables. The specified model is indicated in equation (1):

$X_{t}=\left(G B_{t} \pi_{t} e_{t}\right)$

where all the variables are expressed in logarithms. $G B_{t}$ is the government bond, $\pi_{t}$ is the inflation rate and $e_{t}$ is the exchange rate. Following Kim and Roubini (2008), the real exchange rate is used rather than nominal exchange rate. The empirical application is to model and estimate the dynamic relationship amongst the variables in the estimated model. It is presumed that the model is made up of three endogenous variables and the model is consistent with a dynamically linear stochastic model. This can be specified as follows:

$D(L) \Delta X_{t}=\mu_{t}$

Where L represents the shift operator, $\mu_{t}$ is a stochastic term which is in the form of a vector, and $D_{i}$ are vectors of 3 by 3 matrixes of determinate coefficients. Each component of $\mu_{t}$ means an exogenous shocks. The second moment of the distribution forming the data are abridged by the below World moving average:

$X_{t}=\left(I+D_{1}(L)+D_{2}\left(L^{2}\right)+D_{3}\left(L^{3}\right)\right)=D(L) \mu_{t}$

The $E\left(\mu_{t} \mu_{t}\right)=\Sigma$. Assuming the means of generating data for $X_{t}$ is stationary and also covariance, then limit $_{s \rightarrow \infty} D_{s}=0$. Also, assuming $D(L)$ is invertible, the $D(L)$ coefficient and the $\Sigma$ coefficient can both be obtained directly from the below specified VAR representation:

$A(L) X_{t}=C(L)^{-1} X_{t}=v_{t}$ 
It should be noted that $A(L)$ is a $k^{\text {th }}$ matrix system which is specified in the form of the lag operator $L$ while the system has all the roots inside the unit circle and $v_{t}$ represents a vector with mean being a positive integer. The $v_{t}$ is also an independently and identically distributed shocks and the covariance matrix is represented as $\Sigma$. Also, if $X_{t}$ is non stationary at level with absence of long run cointegration, $F_{l s}$ will congregates to a limiting distribution and of course is the sum of $\chi^{2}$ and as well the unit root distribution. Lin (2008) argued that it is better to difference $X_{t}$ and test causality for differenced VAR since it would produce a more efficient estimates.

\section{Data, Econometric Procedures and Results}

Table 1 offers the brief of the correlation coefficients amongst the three variables. The results indicate a strong, positive and statistically significant relationship between inflation (INF) and the exchange rate (ER). In addition, a weak, but statistically significant positive relationship exists between government bonds (GB) and exchange rate (ER). Interestingly, a negative but non-significant correlation exists between government bonds (GB) and inflation (INF).

Table 1: Correlation Analysis

\begin{tabular}{llll}
\hline Probability & INF & ER & GB \\
\hline INF & 1.0000 & & \\
& ---- & & \\
ER & ---- & & \\
& 0.8565 & 1.0000 & \\
GB & 18.2573 & ---- & \\
& $0.0000^{*}$ & --- & \\
& -0.0569 & 0.1821 & 1.0000 \\
& -0.6279 & 2.0379 & ---- \\
\hline
\end{tabular}

Note: * denotes significance at $5 \%$.

The variables are in liner form i. e in logarithmic form. This is because conclusions made from VAR models could be sensitive to the order of the integration and the presence or otherwise of the trend. The order of integration of the variables was evaluated using the Augmented Dickey-Fuller test (ADF). The results show that all the variables are I (1) or first difference. The Johansen (1988) cointegration test was used to determine the presence or otherwise of long-run cointegration among the variables. The result is presented in Table 2. The empirical results suggest that there exists no cointegration relationship among the estimated variables.

Table 2: Johansen Cointegration Test

\begin{tabular}{|c|c|c|c|c|}
\hline $\begin{array}{l}\text { Hypothesized } \\
\text { No of } C E_{(s)}\end{array}$ & Eigen Value & Trace. Stat & 0.05 Critical Val. & Prob. \\
\hline None & 0.130081 & 24.52488 & 29.79707 & 0.1791 \\
\hline 1 & 0.057863 & 7.941617 & 15.49471 & 0.4717 \\
\hline 2 & 0.007107 & 0.848786 & 3.841466 & 690 \\
\hline
\end{tabular}

Note: Trace statistics indicates no cointegration relationship amongst the variables.

Hamilon (1994) argued theoretically argued that the VAR methodology is constructed on the assumption that the lag order is known. However, in empirical studies and applications, the optimal lag order not known. Consequently, it has to be determined using lag order criteria. The following lag order criteria AIC, FPE, and LR tests suggest a lag order of 3 . This of course is assumed to produce a stable VAR model. Methodically, the required task is whether to estimate a differenced VAR model or a VECM in levels. Given the absence of cointegration among the variables, Hamilton (1994) argued that estimating VECM at first difference is serious mis-specification which would produce a biased result. Hamilton (1994) consequently submits that the VAR estimation should be implemented at first difference among non-cointegrated series. Since the variables are not cointegrated substantiates the adoption of differenced VAR. The results of cointegration are presented in 
Table 3. Evidence from the VAR estimates shows that the first lag of INF has positive and significant effect on the current value. While the first lag and second lag of GB has a positive and significant effect on INF. Also, the first lag of ER has a positive and significant effect on the current value of ER. The second lag of GB is also found to have a negative but significant effect on ER. Interestingly, neither INF nor ER is found to have a significant effect on GB. This is not surprising as the rising expenditure and fall in government revenue have been the foremost drivers of government in most economies.

Table 3: VAR Estimates (Standard Errors in ( ) \& t-Statistics in [ ])

\begin{tabular}{|c|c|c|c|}
\hline & D_INF & D_ER & D_GB \\
\hline \multirow[t]{3}{*}{ D_INF(-1) } & 0.340431 & -0.114439 & -0.041355 \\
\hline & $(0.09207)$ & $(0.11178)$ & $(0.13196)$ \\
\hline & {$[3.69762]^{*}$} & {$[-1.02379]$} & {$[-0.31339]$} \\
\hline \multirow[t]{3}{*}{ D_INF(-2) } & -0.175761 & -0.012340 & -0.028990 \\
\hline & $(0.08853)$ & $(0.10748)$ & $(0.12689)$ \\
\hline & {$[-1.98536]^{*}$} & {$[-0.11481]$} & {$[-0.22847]$} \\
\hline \multirow[t]{3}{*}{ D_ER(-1) } & 0.085693 & 0.253573 & -0.207657 \\
\hline & $(0.08238)$ & $(0.10002)$ & $(0.11808)$ \\
\hline & [ 1.04016$]$ & {$[2.53513]^{*}$} & {$[-1.75860]$} \\
\hline \multirow[t]{3}{*}{ D_ER(-2) } & -0.093314 & 0.041340 & -0.036325 \\
\hline & $(0.08084)$ & $(0.09815)$ & $(0.11587)$ \\
\hline & {$[-1.15424]$} & [ 0.42117] & {$[-0.31348]$} \\
\hline \multirow[t]{3}{*}{ D_GB(-1) } & 0.189850 & 0.097826 & -0.194432 \\
\hline & $(0.06981)$ & $(0.08476)$ & $(0.10006)$ \\
\hline & {$[2.71937]^{*}$} & [ 1.15412$]$ & {$[-1.94308]$} \\
\hline \multirow[t]{3}{*}{ D_GB(-2) } & 0.199721 & -0.190233 & -0.017806 \\
\hline & $(0.06953)$ & $(0.08442)$ & $(0.09966)$ \\
\hline & {$[2.87246]^{*}$} & {$[-2.25350]^{*}$} & {$[-0.17868]$} \\
\hline \multirow[t]{3}{*}{$\mathrm{C}$} & 0.323015 & 0.081633 & 0.050266 \\
\hline & $(0.04923)$ & $(0.05977)$ & $(0.07056)$ \\
\hline & [6.56125] & {$[1.36575]$} & [ 0.71237] \\
\hline
\end{tabular}

Note: * denotes a t-stat significance at $5 \%$.

The main focus of the study is to analyze how inflation and exchange rate responds to changes in government bonds in South Africa. Consequently, we trace the response of one variable to a standard deviation shock to government bonds using impulse response analysis. Tables 4 to 6 depict the impulse response functions of the variables in the model, adopting ten periods as time horizon. This enables us to examine the issues concerning the implications of government bonds for inflation and exchange rate in South Africa. As a result, the response of inflation and exchange rate to government bonds are examined. The first task has to do with how does inflation rate and exchange rate responds to government bonds in South Africa. This provides relevant information on the efficacy of government bonds in containing or managing exchange rate fluctuation and high inflation episodes in South Africa. Table 4 shows the impulse response functions of inflation to shocks to government bonds and exchange rate. The empirical evidence shows that following an expansionary fiscal policy with a shock to government bonds, inflation rate did not immediately respond to 
the shock in the first period but begins to rise in the second period. The upward trend in inflation due to shocks to government bonds continued to the fourth period and began to decline by the fifth period.

The effect of the shocks began to fizzle out towards the tenth period. Also, the response of inflation rate to shocks in exchange rate fluctuates between the second and seventh period before fading away towards the tenth period. While the response of inflation to its own shocks fluctuates between first and seventh month before fading away toward the tenth period.

Table 4: Response of Inflation (D (INF))

\begin{tabular}{llll}
\hline PERIOD & D(INF) & D(ER) & D(GB) \\
\hline 1 & 0.0037 & 0.0000 & 0.0000 \\
2 & 0.0013 & 0.0006 & 0.0010 \\
3 & 0.0002 & 0.0001 & 0.0011 \\
4 & 0.0002 & 0.0003 & 0.0002 \\
5 & 0.0001 & 0.0001 & 0.0001 \\
6 & 0.0001 & 0.0003 & 0.0001 \\
7 & $2.73 \mathrm{E} 05$ & $-5.25 \mathrm{E}-06$ & $-5.20 \mathrm{E}-05$ \\
8 & $4.61 \mathrm{E}-06$ & $-9.65 \mathrm{E}-06$ & $-8.303 \mathrm{E}-05$ \\
9 & $1.74 \mathrm{E}-05$ & $1.20 \mathrm{E}-06$ & $-2.06 \mathrm{E}-05$ \\
10 & $1.06 \mathrm{E}-05$ & $4.39 \mathrm{E}-06$ & $-5.03 \mathrm{E}-06$ \\
\hline
\end{tabular}

Table 5 displays the impulse response functions of the exchange rate to government bonds and inflation shocks. It is clear that after an expansionary fiscal policy with a shock to government bond, there was a positive change in the exchange rate in the second period and response becomes negative in the third period. The negative response continued to period seven. The effect of the shocks began to fizzle out towards the tenth period. Also, the response of the exchange rate to shocks in inflation fluctuates between the first and eight period and consequently fizzles out towards the tenth period. The response of exchange rate to its own shocks fluctuates between positive and negative from the first to the eight-period and begin to fade away in subsequent months.

Table 5: Response of Exchange Rate (D (ER))

\begin{tabular}{lccc}
\hline PERIOD & D(INF) & D(ER) & D(GB) \\
\hline 1 & -0.0043 & 0.0339 & 0.0000 \\
2 & -0.0002 & 0.0106 & 0.0003 \\
3 & -0.0005 & $4.09 \mathrm{E}-05$ & -0.0101 \\
4 & 0.0019 & -0.0021 & -0.0059 \\
5 & 0.0013 & 0.0011 & -0.0014 \\
6 & 0.0010 & -0.0005 & -0.0004 \\
7 & 0.0004 & -0.0007 & -0.0005 \\
8 & 0.0001 & -0.0002 & $2.18 \mathrm{E}-05$ \\
9 & $5.49 \mathrm{E}-06$ & $9.12 \mathrm{E}-05$ & 0.0001 \\
10 & $3.08 \mathrm{E}-05$ & $-1.38 \mathrm{E}-06$ & $9.24 \mathrm{E}-05$ \\
\hline
\end{tabular}

Table 6 displays the impulse response functions of government bonds to inflation and exchange rate shocks. It is clear that consequent upon a shock to the inflation rate, there is a positive response from government bonds and the response becomes negative by the second period up to the $8^{\text {th }}$ period and the effect begins to fizzle out by the tenth period. The exchange rate oscillates from the first up to the eight-period before the effect begins to fade away towards the tenth period. The response of government bond to its own shocks oscillates between positive and negative from the first to the eight-period and begin to fade away in succeeding periods. The study recommends that South African Reserve Bank, as a coordinator of government bonds, should carry out an adequate x-ray of the economic conditions before issuing the government bonds, especially its impeding effects on the exchange rate and inflation rate as it has important implications for exchange rate and inflation rate behaviour.Appropriate mechanisms must also be put in place such as 
blocking of leakages, avoidance of wastefulness so as to ensure judicious and efficient use of income raised from bonds. This would ensure that the probable negative feedbacks of bond raising on inflation and exchange rate are lessened.

Table 6: Response of Government Bonds (D (GB))

\begin{tabular}{llll}
\hline PERIOD & D(INF) & D(ER) & D(GB) \\
\hline 1 & 0.0046 & 0.0197 & 0.0462 \\
2 & -0.0016 & -0.0125 & -0.0093 \\
3 & $-7.19 \mathrm{E}-05$ & -0.0048 & 0.0040 \\
4 & -0.0020 & 0.0060 & 0.0036 \\
5 & -0.0005 & $2.39 \mathrm{E}-05$ & 0.0015 \\
6 & -0.0007 & 0.0001 & -0.0007 \\
7 & $-3.40 \mathrm{E}-06$ & $-9.42 \mathrm{E}-05$ & -0.0002 \\
8 & $-2.37 \mathrm{E}-05$ & 0.0004 & $-4.00 \mathrm{E}-06$ \\
9 & $7.79 \mathrm{E}-05$ & $-9.63 \mathrm{E}-05$ & $-5.71 \mathrm{E}-05$ \\
10 & $2.64 \mathrm{E}-05$ & $-6.79 \mathrm{E}-05$ & -0.0001 \\
\hline
\end{tabular}

Aside from the impulse response analysis, variance decomposition analysis was also evaluated. The impulse response analyses focus on the effects of shocks to the variable on other endogenous variables whereas the variance decomposition splits the variation in an endogenous variable into the component shocks. Consequently, the variance decomposition gives information on the relative importance of each random innovation affecting other variables in our VAR model. The share of the forecast error variance of each variable accounted for by the shocks to each of the variables are reported in tables 7A, 7B and 7C. The tables display the percentage of the forecast error variance for each variable that can be associated to its own shocks and to shocks in the other variables. Reflecting on the results from earlier studies, the principal causes of deviation in all the variables in the VAR system are "own" shocks.

Government bonds are a vital source of the variation in the inflation rate as it accounts for about 13 percent of change, followed by the exchange rate, which accounts for about 3 percent variance for most of the time. Government bond is also found to be a chief source of variance in the exchange rate. It is responsible for less than 1 percent in the first two periods, but consequently account for more than 9 percent variance in the longer period. While the inflation rate determines about 1 percent variance throughout time horizons. Remarkably, the exchange rate is found to be a prime source of changes in government bonds. The exchange rate is responsible for more 15 percent variation in the first two periods and more than 20 percent in the longer time horizon. The inflation rate on the other hand is found to be responsible for less than 1 percent up to the fifth period and subsequently accounts for about 1 percent forecast error variance for the remaining time horizon.

Table 7A: Variance Decomposition Analysis of Inflation (D (INF))

\begin{tabular}{llll}
\hline PERIOD & D(INF) & D(ER) & D(GB) \\
\hline 1 & 100.0000 & 0.000000 & 0.000000 \\
2 & 91.31679 & 2.794471 & 5.888735 \\
3 & 84.47969 & 2.678672 & 12.84163 \\
4 & 83.67381 & 3.291826 & 13.03436 \\
5 & 83.45854 & 3.388613 & 13.15284 \\
6 & 83.00632 & 3.868186 & 13.12549 \\
7 & 82.99502 & 3.867621 & 13.13736 \\
8 & 82.96638 & 3.866774 & 13.16685 \\
9 & 82.96479 & 3.866633 & 13.16858 \\
10 & 82.96470 & 3.866702 & 13.16860 \\
\hline
\end{tabular}


The VAR Granger Causality PairWise Tests shows that there exists a strong causality running from government bonds to inflation, while bi-causality were found between government bonds and the exchange rate. Inflation is found to not cause changes in government bonds rather government bond is to be an important variable causing both the exchange rate and the inflation rate in South Africa. The overriding pictures that emerge from this study are that government bonds are an important policy instrument in the management of exchange rate and the inflation rate in South Africa.

Table 7B: Variance Decomposition Analysis of Exchange Rate (D(ER))

\begin{tabular}{llll}
\hline PERIOD & D(INF) & D(ER) & D(GB) \\
\hline 1 & 1.616087 & 98.38391 & 0.000000 \\
2 & 1.480695 & 98.50692 & 0.012389 \\
3 & 1.389538 & 91.19145 & 7.419011 \\
4 & 1.617987 & 88.74067 & 9.641348 \\
5 & 1.746628 & 88.50047 & 9.752903 \\
6 & 1.823186 & 88.42003 & 9.756783 \\
7 & 1.833610 & 88.39756 & 9.768832 \\
8 & 1.835992 & 88.39591 & 9.768093 \\
9 & 1.835939 & 88.39383 & 9.770227 \\
10 & 1.835993 & 88.39325 & 9.770754 \\
\hline
\end{tabular}

Table 7C: Variance Decomposition Analysis of Government Bonds (D (GB))

\begin{tabular}{llll}
\hline PERIOD & D(INF) & D(ER) & D(GB) \\
\hline 1 & 0.852241 & 15.31578 & 83.83198 \\
2 & 0.873252 & 19.56467 & 79.56208 \\
3 & 0.861129 & 20.13120 & 79.00767 \\
4 & 0.987317 & 21.02625 & 77.98644 \\
5 & 0.997980 & 21.00627 & 77.99575 \\
6 & 1.016898 & 20.99854 & 77.98456 \\
7 & 1.016879 & 20.99845 & 77.98468 \\
8 & 1.016841 & 21.00292 & 77.98024 \\
9 & 1.017043 & 21.00311 & 77.97985 \\
10 & 1.017062 & 21.00315 & 77.97979 \\
\hline
\end{tabular}

This finding furthers buttress the fact that government bonds are found to be an important and predominant source of forecast error variance in both inflation rate and exchange rate in South Africa. Lastly, it was also found that exchange rate causes changes in inflation of significance to the discussion is the testing of causality between the variables.

Table 8: Pairwise Granger Causality Tests

\begin{tabular}{lcll}
\hline Null Hypothesis: & Obs & F-Statistic & Prob. \\
\hline INF does not Granger Cause GB & 116 & 0.46481 & 0.8579 \\
GB does not Granger Cause INF & & 3.10909 & $0.0050^{*}$ \\
& \multirow{2}{*}{116} & 2.28657 & $0.0333^{*}$ \\
ER does not Granger Cause GB & & 2.49644 & $0.0209^{*}$ \\
GB does not Granger Cause ER & \multirow{2}{*}{116} & 2.77644 & $0.0111^{*}$ \\
ER does not Granger Cause INF & & 0.92428 & 0.4911 \\
INF does not Granger Cause ER & & & \\
\hline
\end{tabular}

Note: * denotes significance at $5 \%$. 


\section{Conclusion and Recommendations}

Economic researchers and practitioners across the globe, especially in developing countries, often recommend government bonds as a means of raising revenue in order to reduce the continued fiscal gap largely due to rising expenditure. However, the raising of bonds by government often hinders the performance of other economic fundamentals such as inflation and exchange rate among others as encapsulated in the theoretical literature. This study therefore empirically investigates the dynamic interaction among government bonds, exchange rate and inflation in South Africa using a monthly time series data. Empirical results show that government bonds account for significant variation in the exchange rate and inflation rate within the study period. The causality test also shows the evidence of causality running from government bond to exchange rate, and also to inflation.

\section{References}

Ajayi, R. A. (1991). On the Simultaneous Interactions of External Debt, Exchange Rates, and Other Macroeconomic Variables: The Case of Nigeria (No. 91). Center for Economic Research on Africa, Department of Economics, School of Business Administration, Montclair State College.

Awan, A., Asghar, N. \& Rehman, H. U. (2011). The impact of exchange rate, fiscal deficit and terms of trade on external debt of Pakistan. Australian Journal of Business and Management Research, 1(3), 10-24.

Asonuma, T. (2013). External Debt, Defaults and Exchange Rate Dynamics. http://www.osipp.osakau.ac.jp/ja/event/Aug.01.2013_IPP.pdf. Date of access: 21 June 2018.

Borensztein, E. \& Mauro, P. (2004). The case for GDP-indexed bonds. Economic Policy, 19(38), 166-216.

Calvo, G. A. \& Reinhart, C. M. (2002). Fear of floating. The Quarterly Journal of Economics, 117(2), 379-408.

Cavallo, E. \& Fernández-Arias, E. (2013). Coping with Financial Crises: Latin American Answers to European Questions. International Development Policy, 4(4.2), 7-28.

De Resende, C. (2007). Cross-country estimates of the degree of fiscal dominance and central bank independence. Bank of Canada Working Papers, 36, 1-36.

Draz, M. U. \& Ahmad, F. (2015). External debts and exchange rates of oil-producing and non-oil-producing nations: Evidence from Nigeria and Pakistan. Journal of Advanced Management Science, 3(1), 8-12.

Engen, E. M. \& Hubbard, R. G. (2004). Federal government debt and interest rates. NBER Macroeconomics Annual, 19, 83-138.

Ezirim, C. B. \& Muoghalu, M. I. (2006). Exchange rate determination, foreign investment burden and external debt crisis in less-developed countries: Nigerian experience. International Journal of Business and Economics Perspectives, 1(1), 1-15.

Frankel, J. (2006). On the Yuan: The choice between adjustment under a fixed exchange rate and adjustment under a flexible rate. CESI of Economic Studies, 52(2), 246-275.

Gaffney, M. (2009). Money, Credit, and Crisis. American Journal of Economics and Sociology, 68(4), 983-1038.

Gavin, M. (1989). The stock market and exchange rate dynamics. Journal of International Money and Finance, 8(2), 181-200.

Gurley, J. G. \& Shaw, E. S. (1955). Financial aspects of economic development. The American Economic Review, 45(4), 515-538.

Hamilton, J. (1994). Time series econometrics. New York: Princeton University Press.

Holman, J. A. \& Neanidis, K. C. (2006). Financing government expenditures in an open economy. Journal of Economic Dynamics and Control, 30(8), 1315-1337.

Johansen, S. (1988). Statistical analysis of cointegration vectors. Journal of Economic Dynamics and Control, 12(2-3), 231-254.

Kalderen, L. (1997). Debt management functions and their location. Coordinating Public Debt and Monetary Management. Washington DC: International Monetary Fund, 79-95.

Kim, S. \& Roubini, N. (2008). Twin deficit or twin divergence? Fiscal policy, current account, and real exchange rate in the US. Journal of International Economics, 74(2), 362-383.

Koller, T., Goedhart, M. \& Wessels, D. (2010). Valuation: measuring and managing the value of companies. John Wiley and Sons: New Jersey.

Lastrapes, W. D. (1998). International evidence on equity prices, interest rates and money. Journal of International Money and Finance, 17(3), 377-406. 
Lin, J. L. (2008). Notes on testing causality. Institute of Economics, Academia Sinica, Department of Economics, National Chengchi University.http://faculty.ndhu.edu.tw/ jlin/files/causality_slide.pdf. Date of access: 25 June 2018.

Masuku, J. N. (2001). An Investigation of the Effects of Kenya's External Debt On Exchange Rate Fluctuations. Dissertation submitted to the University.

Neaime, S. (2009). Sustainability of exchange rate policies and external public debt in the Mena region. Journal of Economics and International Finance, 1(2), 59-72.

Obstfeld, M. \& Rogoff, K. (1995). The mirage of fixed exchange rates. Journal of Economic Perspectives, 9(4), 73-96.

Perri, F., Cavallo, M., Kisselev, K. \& Roubini, N. (2004). Exchange rate overshooting and the costs of floating. In Federal Reserve Bank of San Francisco Proceedings. FRB of San Francisco Working Paper No. 2005-07. https://papers.ssrn.com/sol3/papers.cfm?abstract_id=741205. Date of access: 2 July 2018.

Reza, Y., Siregar, Y. R. \& Pontines, V. (2005). External Debt and Exchange Rate Overshooting: The Case of Selected East Asian Countries. Centre for International Economic Studies. Discussion Paper, No. 0520. International Macro and Finance Program. University of Adelaide, Australia.

Roubini, N. \& Sala-i-Martin, X. (1995). A growth model of inflation, tax evasion, and financial repression. Journal of Monetary Economics, 35(2), 275-301.

Sanusi, K. A. \& Akinlo, A. E. (2016). Investigating Fiscal Dominance in Nigeria. European Journal of Sustainable Development, 8(1), 125-131. 